\title{
Alteration in cell cycle-related proteins in lymphoblasts from carriers of the c.709-1G>A PGRN mutation associated with FT LD-TDP dementia
}

Carolina Alquezar ${ }^{1}$, Noemí Esteras ${ }^{1}$, Fernando Bartolomé ${ }^{1}$, José J. Merino², Ainhoa Alzualde ${ }^{2,3}$, Adolfo López de Munain ${ }^{2,3}$, and Ángeles Martín-Requero ${ }^{1,4}$

${ }^{1}$ Department of Cellular and Molecular Medicine, Centro de Investigaciones Biológicas (CSIC), ${ }^{2}$ Department of Neurology and Experimental Unit, Hospital Donostia-Instituto Biodonostia, ${ }^{3}$ Centro de Investigación Biomédica en Red de Enfermedades Neurodegenerativas (CIBERNED), ${ }^{4}$ Centro de Investigación Biomédica en Red de Enfermedades Raras (CIBERER)

Running header: Progranulin haploinsufficiency induced cell cycle dysfunction in nonneuronal cells.

Key words: FTLD, lymphocytes, cell cycle, pRb, CDK6, TDP-43.

Address for correspondence:

Dr. Ángeles Martín-Requero

Centro de Investigaciones Biológicas (CSIC)

Ramiro de Maeztu 9

28040 Madrid, SPAIN

Phone: 34-91-837-3112

Fax: 34-91-536-0432

Email: amrequero@cib.csic.es 


\section{ABSTRACT}

Frontotemporal lobar degeneration with neuronal inclusions containing TDP-43 protein is associated in most cases with null-mutations in the progranulin gene (PGRN). While the mechanisms by which PGRN haploinsufficiency leads to neurodegeneration remained speculative, increasing evidence support the hypothesis that cell cycle reentry of postmitotic neurons precedes many instances of neuronal death. Based in the mitogenic and neurotrophic activities of PGRN, we hypothesized that PGRN deficit may induce cell cycle disturbances and alterations in neuronal vulnerability. Since cell cycle dysfunction is not restricted to neurons, we studied the influence of PGRN haploinsufficiency, on cell cycle control in peripheral cells from patients suffering from frontotemporal dementia, bearing the PGRN mutation c.709-1G $>$ A. Here we show that progranulin deficit increased cell cycle activity in immortalized lymphocytes. This effect was associated with increased levels of CDK6 and phosphorylation of $\mathrm{pRb}$, resulting in a $G_{1} / S$ regulatory failure. A loss of function of TDP-43 repressing CDK6 expression may result from altered subcellular TDP-43 distribution. The distinct functional features of lymphoblastoid cells from c.709-1 G>A carriers offer an invaluable, noninvasive tool to investigate the etiopathogenesis of frontotemporal lobar degeneration 
INTRODUCTION

Frontotemporal lobar degeneration (FTLD) is now a widely recognized form of dementia, characterized by gradual, progressive changes in behavior, personality and/or language with early preservation of memory (Ikeda et al., 2004). It is responsible for at least $20 \%$ of presenil cases (Neary et al., 2000). This heterogeneous disease has been of particular interest to geneticists due to its high rate of heritability with up to $40 \%$ of patients reporting a family history of the disease in at least one extra family member.

The main clinical presentations of FTLD are 1) behavioural bv-FTD, with disinhibition and changes in personality, such as apathy and poor judgment and 2) language, with a nonfluent aphasia with anomia (primary progressive aphasia, PPA), or a fluent aphasia with early loss of word meaning (semantic dementia, SD).

Pathologically, these diseases share deposits of abnormal proteins in neuroectodermic cells, and severe cell loss with atrophy of vulnerable cortical and subcortical structures (Mackenzie et al., 2006). The most common pathology in FTLD, accounting for 40-65\% of cases, has found to be neuritis, neuronal cytoplasmic inclusions, and lentiform intranuclear inclusions, containing as the major component the TAR DNA binding protein 43 (TDP-43) (Arai et al., 2006; Neumann et al., 2006), and thus named FTLDTDP (Mackenzie et al., 2010a). Four different patterns of TDP-43 pathology are recognized in FTLD-TDP, based on the anatomical distribution, morphology, and relative proportion of distinct types of inclusions. (Mackenzie et al., 2010b). This heterogeneity is also supported by different clinical and genetic features. The FTLD-TDP includes the behavioral variant FTD (bv-FTD), PPA and FTD with motor neuron disease (FTD-MND) (Bugiani, 2007). The next largest group of FTLD cases comprises FTLD with taupositive pathology (FTLD-tau) (Kumar-Singh and Van Broeckhoven, 2007), and these patients can present atypical parkinsonism in addition to bv-FTD and PPA. Recently 
another small group of cases has been described to be immunoreactive for FUS (FTLDFUS) mutations of which have been associated with amyotrophic lateral sclerosis (ALS) (Kwiatkowski et al., 2009; Vance et al., 2009). The overlap between ALS and FTD, as well as the homology of FUS and TDP-43 prompted a number of studies that demonstrated that the inclusions of the several tau/TDP-43 negative FTLDs were immunoreactive for FUS (Muñoz et al., 2009; Neuman et al. 2009), including the formerly designed FTLD-UPS because the inclusions were detected with antibodies anti proteins of the ubiquitin proteasome system (UPS) (Mackenzie et al., 2010a).

Mutations in the progranulin gene (PGRN) have been identified as the major cause of FTLD-TDP (Baker et al., 2006; Cruts et al., 2006). All cases of PGRN mutations are recognized as the subtype 1 of FTLD-TDP (Mackenzie et al., 2010b), with most frequent presentations of bv-FTD and PPA (Mackenzie et al., 2010b). Up to now more than 60 different mutations in PGRN have been described associated with the etiology of the disease (http://www.molgen.ua.ac.be/FTDmutations/) (Gijselinck et al., 2008). We have recently described a prevalent ancestral c.709-1G $>$ A mutation related to Basque population (Lopez de Munain et al., 2008; Moreno et al., 2009). The c.709-1G $>$ A mutation results in null allele, as most of the pathogenic mutation described up to now, suggesting that FTLD in these families results from PGRN haploinsufficiency (Baker et al., 2006).

The biological functions of PGRN in the CNS have not been very well studied, and the mechanisms by which PGRN haploinsufficiency leads to neurodegeneration in FTLD remained speculative. PGRN is expressed in neurons and microglia (Ahmed et al., 2007). Some data suggests that PGRN may function as an autocrine neuronal growth factor. For instance, the addition of low concentrations of PGRN can promote mitogenesis in PC12 cells (Zhou et al., 1993). In addition, a possible role for PGRN in CNS inflammation has 
been proposed (Ahmed et al., 2007; Eriksen and Mackenzie, 2008). On these grounds, it seems plausible that neurodegeneration may result from reduced neuronal growth support or protection (Mackenzie, 2007; Neumann et al., 2007).

Studies carried out during last decade have highlighted the important role that cell cycle dysfunction may play in the instigation and progression of neurodegeneration (Wishart et al., 2006). Neuronal changes supporting alterations in cell cycle control in the etiology of neurodegenerative disorders include the ectopic expression of markers of the cell cycle, organelle kinesis, and DNA replication (Copani et al., 2001; Herrup et al., 2004; Zhu et al., 2004). Aberrant induction of cell cycle regulators in postmitotic neurons have been reported in several neurodegenerative diseases such as Alzheimer's disease (AD), ALS, and Parkinson's disease (PD) (Arendt, 2003; Mosch et al., 2007; Yang et al., 2001). Little is known about the involvement of cell cycle-related events in the neurodegenerative process in FTLD. However, it was previously reported (Husseman et al., 2000) the presence of mitotic markers in the frontal cortex of two individuals diagnosed FTLD-17 from the Seattle BK Family carrying the ${ }^{\mathrm{Val}} 279^{\mathrm{Met}}$ tau mutation. These authors also reported changes in cell cycle regulatory proteins in other FTLD-tau diseases such as Corticobasal degeneration (CBD) or Pick disease (Husseman et al., 2000)

A recent report has suggested a possible link between FTLD-TDP and altered cell cycle control (Ayala et al., 2008). Loss of functional nuclear TDP-43 as the consequence of accumulation of the protein in cytoplasm, leads to increased cyclin/CDK activity and retinoblastoma protein phosphorylation $(\mathrm{pRb})$, which is a major determinant for $\mathrm{G}_{1}$ progression (Weinberg, 1995).

The main goal of this work has been to study the influence of PGRN haploinsufficiency in cell cycle regulation of peripheral blood cells, which are easily accessible, from c.7091G $>$ A PGRN mutation carriers (PGRN+ cells). To this end, we have analyzed the 
proliferative activity of lymphoblasts from patients as well as from asymptomatic c.709$1 \mathrm{G}>\mathrm{A}$ carriers and control subjects. Although FTLD symptoms reflect preferential neuronal loss in specific brain regions, PGRN is expressed in almost all tissues, so abnormalities outside the brain might be expected. In fact it is known that PGRN is highly expressed in peripheral blood cells (Coppola et al., 2008) and deficit of PGRN mRNA and/or protein levels, had been detected in lymphocytes from PGRN mutation carriers (Coppola et al., 2008; Finch et al., 2009; Lopez de Munain et al., 2008). The lymphoblastoid cell lines, obtained by infecting peripheral blood mononuclear cells with the Epstein Barr virus (EBV), resemble activated B cells in the expression of activation markers and adhesion molecules (Wang et al., 1990). EBV-immortalized lymphocytes retain the cellular response of fresh obtained lymphocytes, to serum addition or withdrawal. We found similar changes in cell proliferation and survival, as well as in the content of certain regulatory proteins, in these cell lines than untransformed lymphocytes (Bartolome et al., 2007; Munoz et al., 2008), suggesting the usefulness of this experimental model particularly to study cell cycle-related events associated to neurodegeneration (de las Cuevas et al., 2005; de las Cuevas et al., 2003).

We report here a serum-mediated enhancement of proliferation of lymphoblasts from c.709-1G>A carriers, whether or not they have developed dementia. The increased cell proliferation is associated with increased $\mathrm{pRb}$ phosphorylation and CDK6 content. In addition, PGRN+ lymphoblasts show altered subcellular distribution of the TDP-43 protein. The decrease in nuclear TDP-43 in PGRN+ cells may provide an explanation for the increased levels of CDK6 and progression of these cultures through the cell cycle. 


\section{METHODS}

Cell lines

A total of 28 individual were enrolled in this study: 18 carriers of the c.709-1G $>$ A PGRN gene mutation, 6 of them patients of FTLD and 12 asymptomatic, and 10 control individuals without mutation in PGRN nor any sign of neurological degeneration. Asymptomatic and control individuals were relatives of patients. All patients were diagnosed as FTD in the Donostia Hospital by applying consensus criteria as published elsewhere (McKhann et al., 2001). Patients exhibited variable phenotype initial symptoms. Four of them presented the behavioral variant of frontotemporal dementia (bv-FTD), one progressive nonfluent aphasia, and corticobasal basal syndrome (CBS) the other. Patients developed a relatively rapidly progressive dementia with features that led to a secondary diagnosis. Notably, this secondary diagnosis was CBS in three of the bv-FTD cases. A summary of demographic characteristics of all subjects enrolled in this study is reported in Table I.

The PGRN levels in plasma were strongly reduced in affected and unaffected subjects carrying the c. $709-1 \mathrm{G}>$ A mutation $(45 \pm 15 \mathrm{ng} / \mathrm{ml}$ as compared with a mean value of 140 $\mathrm{ng} / \mathrm{ml}$ for control individuals (Alzualde et al., unpublished results)

All study protocols were approved by the Donostia Hospital and the Spanish Council of Higher Research Institutional Review Board and are in accordance with National and European Union Guidelines. In all cases, peripheral blood samples were taken after written informed consent of the patients or their relatives to determine the presence of the c.709-1G>A PGRN mutation and to establish the lymphoblastoid cell lines.

DNA was extracted from blood cells using standard procedures. PGRN gene sequencing procedures used at our laboratory have been published elsewhere (Lopez de 
Munain et al., 2008). For determination of progranulin plasma levels we used an ELISA kit (AdipoGene, Korea).

Establishment of lymphoblastic cell lines was performed in our laboratory as previously described (Ibarreta et al., 1998) by infecting peripheral blood lymphocytes with the Epstein Barr virus (EBV) (Koistinen, 1987). Cells were grown in suspension in T flasks in an upright position, in approximately $10 \mathrm{ml}$ of RPMI-1640 (Invitrogen) medium that contained $2 \mathrm{mM}$ L-glutamine, $100 \mathrm{mg} / \mathrm{ml}$ penicillin/streptomycin and, unless otherwise stated, $10 \%(\mathrm{v} / \mathrm{v})$ fetal bovine serum (FBS) and maintained in a humidified $5 \% \mathrm{CO}_{2}$ incubator at $37{ }^{\circ} \mathrm{C}$. Fluid was routinely changed every two days by removing the medium above the settled cells and replacing it with an equal volume of fresh medium.

Determination of cell proliferation

Proliferation was determined by cell counting in a Neubauer chamber. EBV immortalized lymphocytes from control and PGRN mutation carriers were seeded at an initial cell concentration of $1 \times 10^{6}$ cells $\times \mathrm{ml}^{-1}$. Cells were enumerated everyday thereafter. Potential toxicity of the reagents used was routinely checked by trypan blue exclusion under inverted phase-contrast microscopy.

Cell cycle analysis

Exponentially growing cultures of cell lines were seeded at an initial concentration of 1 x $10^{6}$ cells $\mathrm{x} \mathrm{m}{ }^{-1}$. Cell cycle analysis was performed using a standard method (Krishan, 1975). Cells were fixed in $75 \%$ ethanol for $1 \mathrm{~h}$ at room temperature. Subsequent centrifugation of the samples was followed by incubation of cells in PBS containing 1 $\mathrm{mg} / \mathrm{ml}$ of RNase at room temperature for $20 \mathrm{~min}$ and staining with propidium iodide (PI; $25 \mathrm{mg} / \mathrm{ml}$ ). Cells were analyzed in an EPICS-XL cytofluorimeter (Coulter Científica, Móstoles, Spain). Estimates of cell cycle phase distributions were obtained 
by computer analysis of DNA content distributions.

Immunological analysis

Cell extracts

To prepare whole cell extracts, cells were harvested, washed in PBS and then lysed in ice-cold lysis buffer (50 mM Tris pH 7.4, $150 \mathrm{mM} \mathrm{NaCl}, 50 \mathrm{mM} \mathrm{NaF}, 1 \%$ Nonidet P40), containing $1 \mathrm{mM}$ sodium orthovanadate, $1 \mathrm{mM}$ PMSF, $1 \mathrm{mM}$ sodium pyrophosphate and protease inhibitor Complete Mini Mixture (Roche, Mannhein).

Cytosolic and nuclear proteins were differentially extracted by lysing cells in ice-cold hypotonic buffer (10 mM Hepes, pH 7.9, 10 mM KCl, 0.1 mM EDTA, 0.1 mM EGTA, $1 \mathrm{mM}$ DTT) containing $1 \mathrm{mM}$ sodium orthovanadate, $1 \mathrm{mM}$ PMSF, $1 \mathrm{mM}$ sodium pyrophosphate, and protease inhibitor mixture. After extraction on ice for $15 \mathrm{~min}, 0.5 \%$ Nonidet P-40 was added, and the lysed cells centrifuged at $4000 \mathrm{rpm}$ for $10 \mathrm{~min}$. Supernatants containing cytosolic proteins were centrifuged at $13000 \mathrm{rpm}$ for $10 \mathrm{~min}$. Nuclei were washed twice with the hypotonic buffer, and then lysed in hypertonic buffer (20 mM Hepes, pH 7.9, 0.4 M NaCl, 1 mM EDTA, 1 mM EGTA, 1 mM DTT) containing $1 \mathrm{mM}$ sodium orthovanadate, $1 \mathrm{mM}$ PMSF, $1 \mathrm{mM}$ sodium pyrophosphate and protease inhibitor mixture. After extraction on ice for $30 \mathrm{~min}$, the samples were centrifuged at $15000 \mathrm{rpm}$ for $15 \mathrm{~min}$ at $4^{\circ} \mathrm{C}$. Antibodies to $\beta$-tubulin and to lamin $\mathrm{B} 1$ were used to assess the purity of the fractions.

The protein content of the extracts was determined by the Bio-Rad protein assay kit (Bio-Rad Laboratories, Richmond, CA)

Western blot analysis

50-100 $\mu \mathrm{g}$ of protein from cell extracts were fractionated on a SDS polyacrylamide gel, and transferred to PVDF membrane (Immobilon-P). The amount of protein and the 
integrity of transfer were verified by staining with Ponceau-S solution (Sigma). The membranes were then blocked with non-fat milk and incubated, overnight at $4^{\circ} \mathrm{C}$, with primary antibodies at the following dilutions: 1:500 anti-pRb, 1:500 anti-CDK2, 1:500 anti-CDK4, 1:200 anti-CDK6, 1:500 anti cyclin E, 1:1000 anti cyclin D1, 1:100 anticyclin D2, 1:2000 anti-cyclin D3, 1:500 anti-p27, 1:500 anti-p21, 1:500 anti-p16, 1:200 anti-p18, 1:500 anti-TDP-43, 1:2000 $\beta$-actin, and 1:1000 anti-lamin B1. Signals from the primary antibodies were amplified using species-specific antisera conjugated with horseradish peroxidase (Sigma) and detected with a chemiluminiscent substrate detection system ELC (Amersham). The relative protein levels were determined by scanning the bands with a GS-800 imaging densitometer provided with the Quantity One 4.3.1 software from BioRad.

\section{Confocal laser scanning microscopy}

Immortalyzed lymphocytes from control and c.709-1G $>$ A carriers individuals were seeded at an initial density of $1 \times 10^{6} \mathrm{x} \mathrm{ml}^{-1}$ and incubated in RPMI medium containing $10 \%$ FBS for $48 \mathrm{~h}$.

Cells were fixed for 15 min in $4 \%$ paraformaldehyde in PBS, and blocked and permeabilized with $0.5 \%$ TritonX-100 in PBS-0.5\% BSA for $20 \mathrm{~min}$ at room temperature. Then, cells were incubated with anti-TDP43 polyclonal antibody (Protein Tech Group, Chicago IL, USA). After washing with PBS, cells were incubated with Alexa Fluor 488-conjugated anti-rabbit antibody. When indicated, Alexa Fluor 568 conjugated to phalloidin was added to simultaneously visualize F-actin. For nuclear staining, samples were incubated with DAPI (Sigma) at $4 \mathrm{mg} / \mathrm{ml}$ in PBS for $15 \mathrm{~min}$ at room temperature. The preparations were mounted on FluorSave reagent (Calbiochem) 
and visualizad with the Leica TCS-SP2-AOBS confocal microscope system (Heidelberg, Germany).

\section{Statistical analysis}

Unless otherwise stated, all data represent means \pm standard error of the mean (SE). Statistical analysis was performed on the Data Desk package (version 4.0) for Macintosh. Statistical significance was estimated by the Student's t-test or, when appropriated, by analysis of variance (ANOVA) followed by the Fischer's LSD test for multiple comparisons. Differences were considered significant at a level of $p<0.05$. 


\section{RESULTS}

Proliferative activity of Iymphoblasts from control and PGRN+ individuals.

Fig. 1A shows a time-course analysis of the proliferative activity of lymphoblasts from control and c.709-1G>A carriers, both asymptomatic and FTLD affected cases. For these experiments, cells were seeded at an initial density of $1 \times 10^{6}$ cells $\times \mathrm{ml}^{-1}$ in the presence of $10 \%$ FBS and counted for three days thereafter. Cell counts of c.709-1G $>$ A carriers were significantly higher than those from normal individuals the first day after seeding $(\mathrm{p}<0.05)$, and the increased rate was maintained along 3 days of experiment. No differences were observed between cells from asymptomatic or patients. Fig. 1B depicts scatter plot of the proliferative activity of the lymphoblastoid cell lines used in this study $72 \mathrm{~h}$ after serum stimulation.

Cell cycle disturbances in neurodegenerative disorders appear to involve a $G_{1} / S$ checkpoint failure (Nagy, 2007). For this reason, we find it interesting to determine the cell cycle status of lymphoblasts from control or c.709-1G $>$ A carriers, either asymptomatic or FTLD patients, after $36 \mathrm{~h}$ of serum stimulation. As shown in Fig. 2, the proportion of cells in G1 phase was significantly lower and the proportion of cells in $\mathrm{S}$ phase was significantly higher in PGRN+ cells than those in control cells, $36 \mathrm{~h}$ after of serum stimulation. Again, no differences in cell cycle distribution were found between lymphoblasts from asymptomatic or FTLD patients (Fig. 2). On the other hand we did not observed significant changes in the proportion of sub- $\mathrm{G}_{0} / \mathrm{G}_{1}$ hypodiploid cells, characteristic of apoptosis/necrosis among the groups (Fig. 2), suggesting that the increased cell number in cultures of c.709-1G $>$ A carriers, truly reflects an increase in cell proliferation. 
Expression of key cell cycle regulatory proteins in control and PGRN+ Iymphoblasts.

Passage through the restriction point in late $\mathrm{G}_{1}$ and commitment to DNA synthesis are controlled by the presence and phosphorylation status of pRb (Draetta, 1994; Weinberg, 1995). Hypo- and hyperphosphorylated forms of this protein are easily distinguished in SDS-polyacrylamide gels. Fig. 3 shows the phosphorylation status of pRb in control and PGR + lymphoblasts $48 \mathrm{~h}$ after serum stimulation. It is observed an increase in $\mathrm{pRb}$ phosphorylation in PGRN+ cells, as evidenced by the higher intensity of the slower migrating band (Fig. 3).

The phosphorylation of $\mathrm{pRb}$ is mediated by the cyclin-dependent kinases CDK4/CDK6cyclin D1 and CDK2-cyclin E (Lundberg and Weinberg, 1998; Mittnacht, 1998). As shown in Fig. 4 no differences were observed in the protein levels of cyclins E, D2 and D3 between control or PGRN+ cells. The levels of cyclin D1 were barely detectable in these cell cultures (Fig. 4). Fig 5 shows the cellular content of CDKs. While CDK2 and CDK4 levels were similar in control and PGRN+ lymphoblasts, we detected a significant increase in CDK6 was found in both PGRN+ cells from asymptomatic or FTLD patients (Fig. 5). We then analyzed the cellular content of the members of Cip/Kip or the INK4 family of CDKs inhibitors in control and PGRN+ cells. Results are summarized in Fig. 6. We did not observe differences on either p21 or p27 content between control and PGRN+ cells. Neither we found differences on the INK members, p16 and p18 (Fig. 6). Taken together, these observations suggest that the increased pRb phosphorylation in PGRN+ lymphoblasts may depend on CDK6 activity.

To further analyze the involvement of CDK6 activity on the enhanced proliferation of lymphoblasts bearing the c.709-1G $>$ A PGRN mutation, use was made of the CDK6 inhibitor sodium butyrate (Kim et al., 2007). As shown in Fig. 7A, treatment of PGRN+ 
lymphoblasts with increasing concentrations of sodium butyrate resulted in a significant inhibition of cell proliferation in a dose-dependent manner. Sodium butyrate did not change the proliferation of lymphoblasts from control individuals. We next evaluated the effect of $10 \mu \mathrm{M}$ sodium butyrate on the cellular levels of CDK6. As shown in Fig.7B, treatment of PGRN+ cells with sodium butyrate decreased the content of the CDK6 protein to levels similar to those of control cells. As expected, sodium butyrate was able to decrease the phosphorylation status of $\mathrm{pRb}$ in lymphoblasts from PGRN+ subjects (Fig.7B).

Subcellular distribution of TDP-43.

It has been recently reported that TDP-43, the main protein in the ubiquitin+ inclusions in FTLD brains, negatively regulates the expression of CDK6 (Ayala et al., 2008). On these grounds, we considered the possibility of a loss of function of TDP-43 secondary to changes in the nuclear content of this protein. For this reason, we studied whether there are changes in the subcellular distribution of TDP-43 in PGRN+ cells. To this end control and PGRN+ lymphoblasts were processed for immunostaining and confocal laser scanning microscopy or fractionated to enrich for nuclear or cytoplasmatic proteins. In agreement with previous report (Buratti and Baralle, 2009), TDP-43 predominantly localizes in the nucleus (Fig. 8A), although low levels of TDP-43 are observed in the cytosol. The western blot analysis of nuclear and cytoplasmic proteins reveled in PGRN+ cells, a small, but statistically significant, increase in the cytosolic content of TDP-43 that paralleled the decrease in nuclear levels of TDP-43 (Fig. 8B). 


\section{DISCUSSION}

Accumulating evidence suggests that activation of cell cycle machinery contributes to neuronal dysfunction, and eventual neurodegeneration (Wishart et al., 2006). A cohort of neurodegenerative conditions that present cell cycle alterations have been identified. These include AD, PD, ALS and others (Appert-Collin et al., 2006; Hoglinger et al., 2007). So far, cell cycle disturbances associated with FTLD have been reported for a number of FTLD-tau cases, including carriers of tau mutations or patients bearing tau inclusions (Husseman et al., 2000). Since these disorders are triggered by different etiologic factors, it is suggested that cell cycle activation may be the cellular response to different insults, and alterations of cell cycle regulatory proteins could be a convergent mechanism to neurodegeneration. Previous work from our and other laboratories (Bartolome et al., 2007; de las Cuevas et al., 2005; de las Cuevas et al., 2003; Muñoz et al., 2008; Nagy et al., 2002; Zhou and Jia, 2010) had demonstrated that cell cyclerelated events can be detected outside the central nervous system i.e. in peripheral blood lymphocytes, suggesting, therefore, that these easily accessible cells may represent useful tools to study the mechanisms involved in the pathogenesis of neurodegenerative diseases.

In this study, we have examined the cellular response to serum stimulation of lymphoblasts derived from control and individuals carrying the c.709-1G>A PGRN mutation, either asymptomatic or diagnosed of FTLD. For this purpose, a comparative study on cell proliferation, cell cycle profiles, and expression levels of key cell cycle regulatory proteins was performed. In addition, we investigated potential differences in the subcellular distribution of TDP-43 in control or PGRN+ lymphoblasts.

Lymphoblasts from PGRN+ subjects show cell cycle progress modifications such as a decrease of cells in $\mathrm{G}_{1}$, an increased number of cells in $S$, together with altered 
expression and phosphorylation of $\mathrm{pRb}$ and other proteins involved in cell cycle regulation. $\mathrm{pRb}$ protein functions as a molecular interface coupling the extracellular signals to the transcriptional machinery of the cells (Hatakeyama and Weinberg, 1995). When it is hypophosphorylated, $\mathrm{pRb}$ forms inhibitory complexes with members of E2F family of transcription factors (Chellappan et al., 1991). Upon phosphorylation, $\mathrm{pRb}$ releases E2F, allowing them to promote the transcription of gene products necessary for cell cycle progression (Helin, 1998).

$\mathrm{pRb}$ is sequentially phosphorylated by two sets of protein kinases, the cyclin D/CDK4/CDK6 and cyclin E/CDK2 complexes (Mittnacht, 1998). We did not observe differences in the levels of expression of cyclins D and E or in the kinases CDK4 and CDK2 between control and PGRN+ cells. However, a significant increase in cellular content in CDK6 protein was observed in PGRN+ lymphoblasts from FTLD patients. The cellular content of CDK inhibitors, either of the Cip/Kip family or the INK4 family was not influenced by PGRN deficiency. Therefore, the observed increase in the amount of hyperphosphorylated $\mathrm{pRb}$ in PGRN+ lymphoblasts seems to be the result of enhanced CDK6 activity.

The activity and expression of CDK6 is amplified in a number of tumors (BritoBabapulle et al., 2002; Timmermann et al., 1997). Recently, it has been reported that CDK6 is repressed by TDP-43 (Ayala et al., 2008). The control of CDK6 expression mediated by TDP-43 involves GT repeats in the target gene sequence. The repeat traces are present once or twice in all of the larger introns. In contrast, introns in other human CDK genes, e.g., CDK4 and CDK2, are significantly shorter and lack (GT)n (Ayala et al., 2008). Although these studies were performed in non-neuronal cells, increased CDK activity and $\mathrm{pRb}$ phosphorylation have linked to neuronal death in a number of cell and animal models of neurodegeneration (Greene et al., 2007; Nguyen et al., 2002). Recent 
studies have indicated that PGRN deficiency may result in a caspase-mediated cleavage of TDP-43 leading to mislocalization of TDP-43 to insoluble cytosolic fraction (Dormann et al., 2009; Zhang et al., 2007). Our results indicate that PGRN+ cells display a small but significant decrease in the nuclear content of TDP-43. Taken together, these observations suggest that a loss of nuclear TDP-43 function in repressing CDK6, may be involved in the increased $\mathrm{pRb}$ phosphorylation, and enhanced proliferative activity of PGRN+ cells.

Our results show no differences in the proliferative activity and cellular content of CDK6 among lymphoblasts derived from FTLD patients presenting different clinical presentation (bv-FTD, PPA or CBS). Moreover, we had not observed significant differences between c.709-1G $>$ A mutation carriers whether asymptomatic or with clinical signs of dementia. Since most of the asymptomatic carriers are younger than the patients (Table I), this finding suggests that cell cycle disturbances may be early manifestations of the disease. However, we observed that some PGRN+ individuals remain asymptomatic until advanced age. For example, only one of four brothers (age 63-71), carriers of c.709-1G>A mutation was diagnosed of FTLD. This observation indicates the existence of modifiers factors (either genetic or environmental) in determining the onset of clinical disease.

In summary, our results established a molecular link between mislocalization of TDP43 and increased CDK6 levels, pRb phosphorylation and proliferation of lymphoblasts from c.709-1G $>$ A carriers. Assuming that the cell cycle disturbances reported here could be peripheral signs of the disease, our results suggest that neurons of c.709-1 $\mathrm{G}>\mathrm{A}$ mutation carriers are at high risk of entering an unscheduled cell cycle that would then drive them to death. It is suggested that therapeutical interventions aimed at ameliorating cell cycle progression activity may have a positive impact in FTLD. 


\section{ACKNOWLEDGMENTS}

This work has been supported by grants from Ministry of Education and Science (SAF2007-62405, SAF2010-15700), Fundación Eugenio Rodríguez Pascual, Diputación Foral de Gipuzkoa (76/08) and Basque Government (Saiotek program). NE holds a fellowship of the JAE predoctoral program of the CSIC. JJ Merino holds a contract of the Ramon y Cajal Program of the Spanish Ministry of Science and Innovation.

\section{CONFLICT OF INTEREST}

The authors declare that they have no conflict of interest. 


\section{REFERENCES}

Ahmed, Z., Mackenzie, I.R., Hutton, M.L., Dickson, D.W., 2007. Progranulin in frontotemporal lobar degeneration and neuroinflammation. $\mathrm{J}$ Neuroinflammation. 47.

Appert-Collin, A., Hugel, B., Levy, R., Niederhoffer, N., Coupin, G., Lombard, Y., Andre, P., Poindron, P., Gies, J.P., 2006. Cyclin dependent kinase inhibitors prevent apoptosis of postmitotic mouse motoneurons. Life Sci. 79(5), 484-490.

Arai, T., Hasegawa, M., Akiyama, H., Ikeda, K., Nonaka, T., Mori, H., Mann, D., Tsuchiya, K., Yoshida, M., Hashizume, Y., Oda, T., 2006. TDP-43 is a component of ubiquitin-positive tau-negative inclusions in frontotemporal lobar degeneration and amyotrophic lateral sclerosis. Biochem Biophys Res Commun. 351(3), 602-611.

Arendt, T., 2003. Synaptic plasticity and cell cycle activation in neurons are alternative effector pathways: the 'Dr. Jekyll and Mr. Hyde concept' of Alzheimer's disease or the yin and yang of neuroplasticity. Prog Neurobiol. 71(2-3), 83-248.

Ayala, Y.M., Misteli, T., Baralle, F.E., 2008. TDP-43 regulates retinoblastoma protein phosphorylation through the repression of cyclin-dependent kinase 6 expression. Proc Natl Acad Sci U S A. 105(10), 3785-3789.

Baker, M., Mackenzie, I.R., Pickering-Brown, S.M., Gass, J., Rademakers, R., Lindholm, C., Snowden, J., Adamson, J., Sadovnick, A.D., Rollinson, S., Cannon, A., Dwosh, E., Neary, D., Melquist, S., Richardson, A., Dickson, D., Berger, Z., Eriksen, J., Robinson, T., Zehr, C., Dickey, C.A., Crook, R., McGowan, E., Mann, D., Boeve, B., Feldman, H., Hutton, M., 2006. Mutations in progranulin cause tau-negative frontotemporal dementia linked to chromosome 17. Nature. 442(7105), 916-919. 
Bartolome, F., de Las Cuevas, N., Munoz, U., Bermejo, F., Martin-Requero, A., 2007. Impaired apoptosis in lymphoblasts from Alzheimer's disease patients: cross-talk of Ca2+/calmodulin and ERK1/2 signaling pathways. Cell Mol Life Sci. 64(11), $1437-1448$.

Brito-Babapulle, V., Gruszka-Westwood, A.M., Platt, G., Andersen, C.L., Elnenaei, M.O., Matutes, E., Wotherspoon, A.C., Weston-Smith, S.G., Catovsky, D., 2002. Translocation $\mathrm{t}(2 ; 7)(\mathrm{p} 12 ; \mathrm{q} 21-22)$ with dysregulation of the CDK6 gene mapping to 7q21-22 in a non-Hodgkin's lymphoma with leukemia. Haematologica. 87(4), 357-362.

Bugiani, O., 2007. The many ways to frontotemporal degeneration and beyond. Neurol Sci. 28(5), 241-244.

Buratti, E., Baralle, F.E., 2009. The molecular links between TDP-43 dysfunction and neurodegeneration. Adv Genet. 661-34.

Chellappan, S.P., Hiebert, S., Mudryj, M., Horowitz, J.M., Nevins, J.R., 1991. The E2F transcription factor is a cellular target for the RB protein. Cell. 65(6), 10531061.

Copani, A., Uberti, D., Sortino, M.A., Bruno, V., Nicoletti, F., Memo, M., 2001. Activation of cell-cycle-associated proteins in neuronal death: a mandatory or dispensable path? Trends Neurosci. 24(1), 25-31.

Coppola, G., Karydas, A., Rademakers, R., Wang, Q., Baker, M., Hutton, M., Miller, B.L., Geschwind, D.H., 2008. Gene expression study on peripheral blood identifies progranulin mutations. Ann Neurol. 64(1), 92-96. 
Cruts, M., Gijselinck, I., van der Zee, J., Engelborghs, S., Wils, H., Pirici, D., Rademakers, R., Vandenberghe, R., Dermaut, B., Martin, J.J., van Duijn, C., Peeters, K., Sciot, R., Santens, P., De Pooter, T., Mattheijssens, M., Van den Broeck, M., Cuijt, I., Vennekens, K., De Deyn, P.P., Kumar-Singh, S., Van Broeckhoven, C., 2006. Null mutations in progranulin cause ubiquitin-positive frontotemporal dementia linked to chromosome 17q21. Nature. 442(7105), 920924.

de las Cuevas, N., Munoz, U., Hermida, O.G., Martin-Requero, A., 2005. Altered transcriptional regulators in response to serum in immortalized lymphocytes from Alzheimer's disease patients. Neurobiol Aging. 26(5), 615-624.

de las Cuevas, N., Urcelay, E., Hermida, O.G., Saiz-Diaz, R.A., Bermejo, F., Ayuso, M.S., Martin-Requero, A., 2003. Ca2+/calmodulin-dependent modulation of cell cycle elements $\mathrm{pRb}$ and p27kip1 involved in the enhanced proliferation of lymphoblasts from patients with Alzheimer dementia. Neurobiol Dis. 13(3), 254-263.

Dormann, D., Capell, A., Carlson, A.M., Shankaran, S.S., Rodde, R., Neumann, M., Kremmer, E., Matsuwaki, T., Yamanouchi, K., Nishihara, M., Haass, C., 2009. Proteolytic processing of TAR DNA binding protein-43 by caspases produces C-terminal fragments with disease defining properties independent of progranulin. J Neurochem. 110(3), 1082-1094.

Draetta, G.F., 1994. Mammalian G1 cyclins. Curr Opin Cell Biol. 6(6), 842-846.

Eriksen, J.L., Mackenzie, I.R., 2008. Progranulin: normal function and role in neurodegeneration. J Neurochem. 104(2), 287-297. 
Finch, N., Baker, M., Crook, R., Swanson, K., Kuntz, K., Surtees, R., Bisceglio, G., Rovelet-Lecrux, A., Boeve, B., Petersen, R.C., Dickson, D.W., Younkin, S.G., Deramecourt, V., Crook, J., Graff-Radford, N.R., Rademakers, R., 2009. Plasma progranulin levels predict progranulin mutation status in frontotemporal dementia patients and asymptomatic family members. Brain. 132(Pt 3), 583-591.

Gijselinck, I., Van Broeckhoven, C., Cruts, M., 2008. Granulin mutations associated with frontotemporal lobar degeneration and related disorders: an update. Hum Mutat. 29(12), 1373-1386.

Greene, L.A., Liu, D.X., Troy, C.M., Biswas, S.C., 2007. Cell cycle molecules define a pathway required for neuron death in development and disease. Biochim Biophys Acta. 1772(4), 392-401.

Hatakeyama, M., Weinberg, R.A., 1995. The role of RB in cell cycle control. Prog Cell Cycle Res. 19-19.

Helin, K., 1998. Regulation of cell proliferation by the E2F transcription factors. Curr Opin Genet Dev. 8(1), 28-35.

Herrup, K., Neve, R., Ackerman, S.L., Copani, A., 2004. Divide and die: cell cycle events as triggers of nerve cell death. J Neurosci. 24(42), 9232-9239.

Hoglinger, G.U., Breunig, J.J., Depboylu, C., Rouaux, C., Michel, P.P., AlvarezFischer, D., Boutillier, A.L., Degregori, J., Oertel, W.H., Rakic, P., Hirsch, E.C., Hunot, S., 2007. The $\mathrm{pRb} / \mathrm{E} 2 \mathrm{~F}$ cell-cycle pathway mediates cell death in Parkinson's disease. Proc Natl Acad Sci U S A. 104(9), 3585-3590.

Husseman, J.W., Nochlin, D., Vincent, I., 2000. Mitotic activation: a convergent mechanism for a cohort of neurodegenerative diseases. Neurobiol Aging. 21(6), $815-828$. 
Ibarreta, D., Urcelay, E., Parrilla, R., Ayuso, M.S., 1998. Distinct pH homeostatic features in lymphoblasts from Alzheimer's disease patients. Ann Neurol. 44(2), 216-222.

Ikeda, M., Ishikawa, T., Tanabe, H., 2004. Epidemiology of frontotemporal lobar degeneration. Dement Geriatr Cogn Disord. 17(4), 265-268.

Kim, J., Park, H., Im, J.Y., Choi, W.S., Kim, H.S., 2007. Sodium butyrate regulates androgen receptor expression and cell cycle arrest in human prostate cancer cells. Anticancer Res. 27(5A), 3285-3292.

Koistinen, P., 1987. Human peripheral blood and bone marrow cell separation using density gradient centrifugation on Lymphoprep and Percoll in haematological diseases. Scand J Clin Lab Invest. 47(7), 709-714.

Krishan, A., 1975. Rapid flow cytofluorometric analysis of mammalian cell cycle by propidium iodide staining. J Cell Biol. 66(1), 188-193.

Kumar-Singh, S., Van Broeckhoven, C., 2007. Frontotemporal lobar degeneration: current concepts in the light of recent advances. Brain Pathol. 17(1), 104-114.

Kwiatkowski, T.J., Jr., Bosco, D.A., Leclerc, A.L., Tamrazian, E., Vanderburg, C.R., Russ, C., Davis, A., Gilchrist, J., Kasarskis, E.J., Munsat, T., Valdmanis, P., Rouleau, G.A., Hosler, B.A., Cortelli, P., de Jong, P.J., Yoshinaga, Y., Haines, J.L., Pericak-Vance, M.A., Yan, J., Ticozzi, N., Siddique, T., McKenna-Yasek, D., Sapp, P.C., Horvitz, H.R., Landers, J.E., Brown, R.H., Jr., 2009. Mutations in the FUS/TLS gene on chromosome 16 cause familial amyotrophic lateral sclerosis. Science. 323(5918), 1205-1208.

Lopez de Munain, A., Alzualde, A., Gorostidi, A., Otaegui, D., Ruiz-Martinez, J., Indakoetxea, B., Ferrer, I., Perez-Tur, J., Saenz, A., Bergareche, A., Barandiaran, M., Poza, J.J., Zabalza, R., Ruiz, I., Urtasun, M., Fernandez- 
Manchola, I., Olasagasti, B., Espinal, J.B., Olaskoaga, J., Ruibal, M., Moreno, F., Carrera, N., Masso, J.F., 2008. Mutations in progranulin gene: clinical, pathological, and ribonucleic acid expression findings. Biol Psychiatry. 63(10), 946-952.

Lundberg, A.S., Weinberg, R.A., 1998. Functional inactivation of the retinoblastoma protein requires sequential modification by at least two distinct cyclin-cdk complexes. Mol Cell Biol. 18(2), 753-761.

Mackenzie, I.R., 2007. The neuropathology and clinical phenotype of FTD with progranulin mutations. Acta Neuropathol. 114(1), 49-54.

Mackenzie, I.R., Rademakers, R., Neumann, M., 2010a. TDP-43 and FUS in amyotrophic lateral sclerosis and frontotemporal dementia. Lancet Neurol. 9(10), 995-1007.

Mackenzie, I.R., Shi, J., Shaw, C.L., Duplessis, D., Neary, D., Snowden, J.S., Mann, D.M., 2006. Dementia lacking distinctive histology (DLDH) revisited. Acta Neuropathol. 112(5), 551-559.

Mackenzie, I.R., Neumann, M., Bigio, E.H., Cairns, N.J., Alafuzoff, I., Kril, J., Kovacs, G.G., Ghetti, B., Halliday, G., Holm, I.E., Ince, P.G., Kamphorst, W., Revesz, T., Rozemuller, A.J., Kumar-Singh, S., Akiyama, H., Baborie, A., Spina, S., Dickson, D.W., Trojanowski, J.Q., Mann, D.M., 2010b. Nomenclature and nosology for neuropathologic subtypes of frontotemporal lobar degeneration: an update. Acta Neuropathol. 119(1), 1-4.

McKhann, G.M., Albert, M.S., Grossman, M., Miller, B., Dickson, D., Trojanowski, J.Q., 2001. Clinical and pathological diagnosis of frontotemporal dementia: 
report of the Work Group on Frontotemporal Dementia and Pick's Disease. Arch Neurol. 58(11), 1803-1809.

Mittnacht, S., 1998. Control of pRB phosphorylation. Curr Opin Genet Dev. 8(1), 2127.

Moreno, F., Indakoetxea, B., Barandiaran, M., Alzualde, A., Gabilondo, A., Estanga, A., Ruiz, J., Ruibal, M., Bergareche, A., Marti-Masso, J.F., Lopez de Munain, A., 2009. "Frontotemporoparietal" dementia: clinical phenotype associated with the c.709-1G>A PGRN mutation. Neurology. 73(17), 1367-1374.

Mosch, B., Morawski, M., Mittag, A., Lenz, D., Tarnok, A., Arendt, T., 2007. Aneuploidy and DNA replication in the normal human brain and Alzheimer's disease. J Neurosci. 27(26), 6859-6867.

Munoz, D.G., Neumann, M., Kusaka, H., Yokota, O., Ishihara, K., Terada, S., Kuroda, S., Mackenzie, I.R., 2009. FUS pathology in basophilic inclusion body disease. Acta Neuropathol. 118(5), 617-627.

Munoz, U., Bartolome, F., Bermejo, F., Martin-Requero, A., 2008. Enhanced proteasome-dependent degradation of the CDK inhibitor p27(kip1) in immortalized lymphocytes from Alzheimer's dementia patients. Neurobiol Aging. 29(10), 1474-1484.

Nagy, Z., 2007. The dysregulation of the cell cycle and the diagnosis of Alzheimer's disease. Biochim Biophys Acta. 1772(4), 402-408.

Nagy, Z., Combrinck, M., Budge, M., McShane, R., 2002. Cell cycle kinesis in lymphocytes in the diagnosis of Alzheimer's disease. Neurosci Lett. 317(2), 8184. 
Neary, D., Snowden, J.S., Mann, D.M., 2000. Classification and description of frontotemporal dementias. Ann N Y Acad Sci. 92046-51.

Neumann, M., Rademakers, R., Roeber, S., Baker, M., Kretzschmar, H.A., Mackenzie, I.R., 2009. A new subtype of frontotemporal lobar degeneration with FUS pathology. Brain. 132(Pt 11), 2922-2931.

Neumann, M., Kwong, L.K., Truax, A.C., Vanmassenhove, B., Kretzschmar, H.A., Van Deerlin, V.M., Clark, C.M., Grossman, M., Miller, B.L., Trojanowski, J.Q., Lee, V.M., 2007. TDP-43-positive white matter pathology in frontotemporal lobar degeneration with ubiquitin-positive inclusions. J Neuropathol Exp Neurol. 66(3), 177-183.

Neumann, M., Sampathu, D.M., Kwong, L.K., Truax, A.C., Micsenyi, M.C., Chou, T.T., Bruce, J., Schuck, T., Grossman, M., Clark, C.M., McCluskey, L.F., Miller, B.L., Masliah, E., Mackenzie, I.R., Feldman, H., Feiden, W., Kretzschmar, H.A., Trojanowski, J.Q., Lee, V.M., 2006. Ubiquitinated TDP-43 in frontotemporal lobar degeneration and amyotrophic lateral sclerosis. Science. 314(5796), 130-133.

Nguyen, M.D., Mushynski, W.E., Julien, J.P., 2002. Cycling at the interface between neurodevelopment and neurodegeneration. Cell Death Differ. 9(12), 1294-1306.

Timmermann, S., Hinds, P.W., Munger, K., 1997. Elevated activity of cyclin-dependent kinase 6 in human squamous cell carcinoma lines. Cell Growth Differ. 8(4), 361-370.

Vance, C., Rogelj, B., Hortobagyi, T., De Vos, K.J., Nishimura, A.L., Sreedharan, J., Hu, X., Smith, B., Ruddy, D., Wright, P., Ganesalingam, J., Williams, K.L., Tripathi, V., Al-Saraj, S., Al-Chalabi, A., Leigh, P.N., Blair, I.P., Nicholson, G., 
de Belleroche, J., Gallo, J.M., Miller, C.C., Shaw, C.E., 2009. Mutations in FUS, an RNA processing protein, cause familial amyotrophic lateral sclerosis type 6 . Science. 323(5918), 1208-1211.

Wang, F., Gregory, C., Sample, C., Rowe, M., Liebowitz, D., Murray, R., Rickinson, A., Kieff, E., 1990. Epstein-Barr virus latent membrane protein (LMP1) and nuclear proteins 2 and $3 \mathrm{C}$ are effectors of phenotypic changes in B lymphocytes: EBNA-2 and LMP1 cooperatively induce CD23. J Virol. 64(5), 2309-2318.

Weinberg, R.A., 1995. The retinoblastoma protein and cell cycle control. Cell. 81(3), 323-330.

Wishart, T.M., Parson, S.H., Gillingwater, T.H., 2006. Synaptic vulnerability in neurodegenerative disease. J Neuropathol Exp Neurol. 65(8), 733-739.

Yang, Y., Geldmacher, D.S., Herrup, K., 2001. DNA replication precedes neuronal cell death in Alzheimer's disease. J Neurosci. 21(8), 2661-2668.

Zhang, Y.J., Xu, Y.F., Dickey, C.A., Buratti, E., Baralle, F., Bailey, R., PickeringBrown, S., Dickson, D., Petrucelli, L., 2007. Progranulin mediates caspasedependent cleavage of TAR DNA binding protein-43. J Neurosci. 27(39), 10530-10534.

Zhou, J., Gao, G., Crabb, J.W., Serrero, G., 1993. Purification of an autocrine growth factor homologous with mouse epithelin precursor from a highly tumorigenic cell line. J Biol Chem. 268(15), 10863-10869.

Zhou, X., Jia, J., 2010. P53-mediated G(1)/S checkpoint dysfunction in lymphocytes from Alzheimer's disease patients. Neurosci Lett. 468(3), 320-325.

Zhu, X., Raina, A.K., Perry, G., Smith, M.A., 2004. Alzheimer's disease: the two-hit hypothesis. Lancet Neurol. 3(4), 219-226. 
TABLE I

\begin{tabular}{lccc}
\hline & Control & \multicolumn{2}{c}{ c.709-1 G>A carriers } \\
\cline { 3 - 4 } & $\mathrm{n}=10$ & $\mathrm{n}=12$ & $\mathrm{n}=6$ \\
& $52 \pm 4$ & $53 \pm 4$ & $65 \pm 3$ \\
Age (years) & $(31-70)$ & $(35-72)$ & $(54-70)$ \\
Age range & & & FTDL Patients \\
Gender (Male/Female) & $5 / 5$ & $6 / 6$ & $0 / 6$ \\
\hline
\end{tabular}

Control: individuals without sign of neurological degeneration; c.709-1G>A: PGRN Progranulin mutation; n: number of subjects. Values are expressed as mean $\pm \mathrm{SE}$. 
Legends to the Figures

Fig. 1

Proliferation of lymphoblasts from control subjects and PGRN mutation c.709-1 G $>$ A carriers.

(A) Immortalized lymphoblasts from control (open circles), PGRN mutation carriers asymptomatic (filled triangles), and carriers affected of FTLD (filled circles) were seeded at an initial density of $1 \times 10^{6} \mathrm{ml}^{-1}$ and cultured for 3 days in RPMI medium containing 10\% FBS. Everyday thereafter, samples were taken for cell counting. Values shown are the mean \pm SE. (B) Scatter plots comparing proliferative activity between control and PGRN+ lymphoblasts after $72 \mathrm{~h}$ of serum stimulation.

Fig. 2

Cell cycle distribution of lymphoblasts in control subjects and PGRN mutation c.709-1 G>A carriers.

The experimental conditions are identical to those described in the legend to Fig. 1. After $36 \mathrm{~h}$ of serum stimulation, cells were harvested, fixed, and analyzed by flow cytometry as described under Methods. Labels show areas of curve corresponding to $\mathrm{G}_{0} / \mathrm{G}_{1}, \mathrm{~S}$, and $\mathrm{G}_{2} / \mathrm{M}$ phases of cell cycle. The percentages of cells in the different phases of cell cycle are summarized below. Data shown are the mean \pm SE of different experiments carried out with cell lines from six control subjects, asymptomatic or FTLD patients, carrying the PGRN c.709-1 G $>$ A mutation, respectively. ${ }^{*} \mathrm{p}<0.05$ significantly different from control cells. 
Fig. 3

Influence of the PGRN mutation C.709-1G>A on $p R b$ levels and phosphorylation status.

Immortalized lymphoblasts from control and PGRN mutation carriers, either asymptomatic or FTLD patients, were seeded at an initial density of $1 \times 10^{6} \mathrm{ml}^{-1}$ and cultured in RPMI medium containing 10\% FBS. After 2 days of culture, cells were harvested and $\mathrm{pRb}$ was detected by immunobloting using a phospho-specific anti-pRb antibody. Two different experiments are shown. $\mathrm{pp}=$ the hyperphosphorylated form of the $\mathrm{Rb}$ protein.

Fig. 4

Cellular content of the Cyclin family of proteins involved in G1 regulation in serum-stimulate lymphoblasts from control or PGRN mutation carriers

Cells were seeded at an initial density of $1 \times 10^{6} \mathrm{x} \mathrm{ml}^{-1}$. Two days after stimulation with $10 \%$ FBS, samples were taken from each culture and total cellular proteins were separated on denaturing gels and immunobloted with the appropriate antibody as shown in the figure. Immunoreactive proteins were visualized with the enhanced chemiluminiscence detection system. The densitometric data represent the mean $\pm \mathrm{SE}$ for of at least 6 independent experiments carried out in cell lines derived from different individuals. 
Fig. 5

Cellular content of the CDK family of proteins involved in $G_{1}$ regulation in serumstimulate lymphoblasts from control or PGRN mutation carriers.

The experimental conditions were identical to those for Fig. 4. Representative immunoblots are shown, while below the densitometric analyses are presented. Data shown represent the mean \pm S.E. for at least 6 different experiments carried out in cell lines derived from different individuals.

Fig. 6

Cellular content of the CDK inhibitors involved in $G_{1}$ regulation in serumstimulate lymphoblasts from control or PGRN mutation carriers.

The levels of the CDK inhibitors either the Cip1/Kip1 or the INK families were determined after two days of serum stimulation. Representative immunoblots are presented. The densitometric data represent the mean \pm SE for of at least 6 independent experiments carried out in cell lines derived from different individuals.

Fig. 7

Effect of increasing concentrations of sodium butyrate on proliferation of Iymphoblasts from control and carriers of the C-709-1G>A PGRN mutation.

(A) Lymphoblasts from control and PGRN+ individuals were seeded at an initial density of $1 \times 10^{6} \mathrm{x} \mathrm{ml}^{-1}$ in RPMI medium containing $10 \% \mathrm{FBS}$, in the presence of increasing concentrations of sodium butyrate and cultured for 3 days. Values shown are the mean $\pm \mathrm{SE}$ for, at least, 6 independent experiments carried out with different individuals. ${ }^{*} p<0.01$ significantly different from control cells.; $* * p<0.01$ significantly 
different from PGRN+ lymphoblasts in the absence of sodium butyrate. (B) The effects of $10 \mu \mathrm{M}$ sodium butyrate on CDK6 content and $\mathrm{pRb}$ phosphorylation status in control and PGRN+ lymphoblasts were evaluated $48 \mathrm{~h}$ after the addition of sodium butyrate. Five independent experiments were performed obtaining similar results. The mean values for $\mathrm{CDK} 6 / \beta$-actin ratios were $0.55 \pm 0.01,0.81 \pm 0.09$, and $0.84 \pm 0.07$ in the absence of sodium butyrate and $0.53 \pm 0.1,0.53 \pm 0.06$, and $0.53 \pm 0.08$ in the presence of sodium butyrate for control, asymptomatic PGRN+, and patients respectively. Differences found in PGRN+ cells incubated in the presence of sodium butyrate were statistically significant $(\mathrm{p}<0.05)$. Representative immunoblots are shown. pp: hyperphosphorylated form of $\mathrm{pRb}$.

Fig. 8

Influence of the PGRN mutation c.709-1G>A on the subcellular localization of TDP-43 protein.

(A) Lymphoblasts from control and PGRN+ individuals were seeded at an initial density of $1 \times 10^{6} \times \mathrm{ml}^{-1}$ and incubated during $48 \mathrm{~h}$ in RPMI medium containing $10 \%$ FBS. TDP-43 protein localization was assessed by confocal laser scanning microscopy. Cells were stained with anti-TDP-43 antibody followed by secondary antibody labeled with Alexa Fluor 488. DAPI and phaloidin were used for nuclear or cytosolic staining respectively. Merged images depict a predominant nuclear localization for TDP-43 protein. Magnification (63X). (B) Cells were harvested after $48 \mathrm{~h}$ of serum stimulation and fractionated to determine by immunoblot the localization of of TDP-43. Antibodies to $\beta$-tubulin and to lamin B1 were used as control of purity and loading of cytoplasmic and nuclearprotein extracts, respectively. Representative immunoblots are shown, 
whereas the densitometric analysis is presented below. Data represent mean $\pm \mathrm{SE}$ for at least 6 experiments. ${ }^{*} \mathrm{p}<0.05$ significantly different from control lymphoblasts. 


\section{Fig.1}

Click here to download high resolution image

A



B

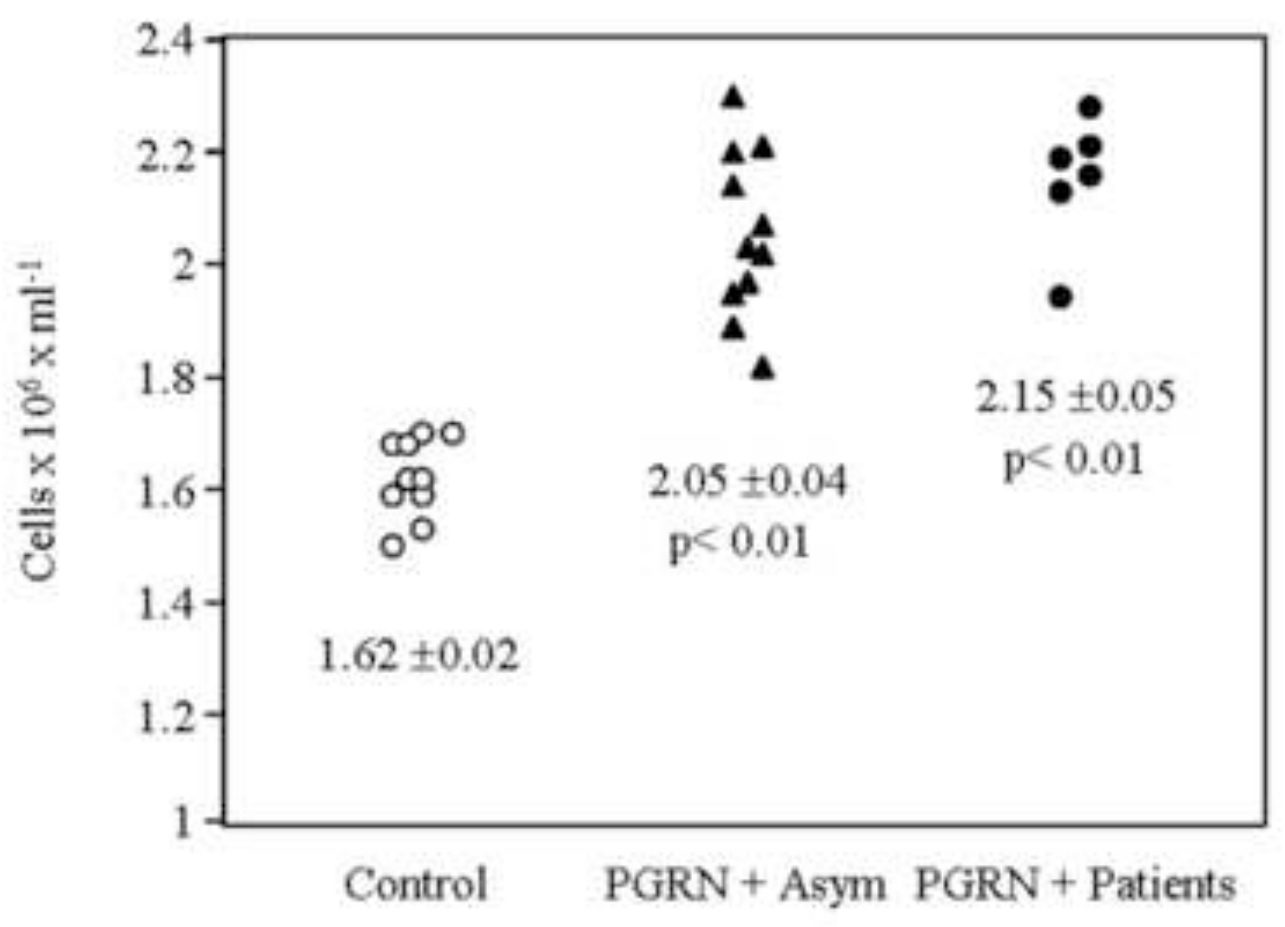

Fig. 1 
Fig.2

Click here to download high resolution image
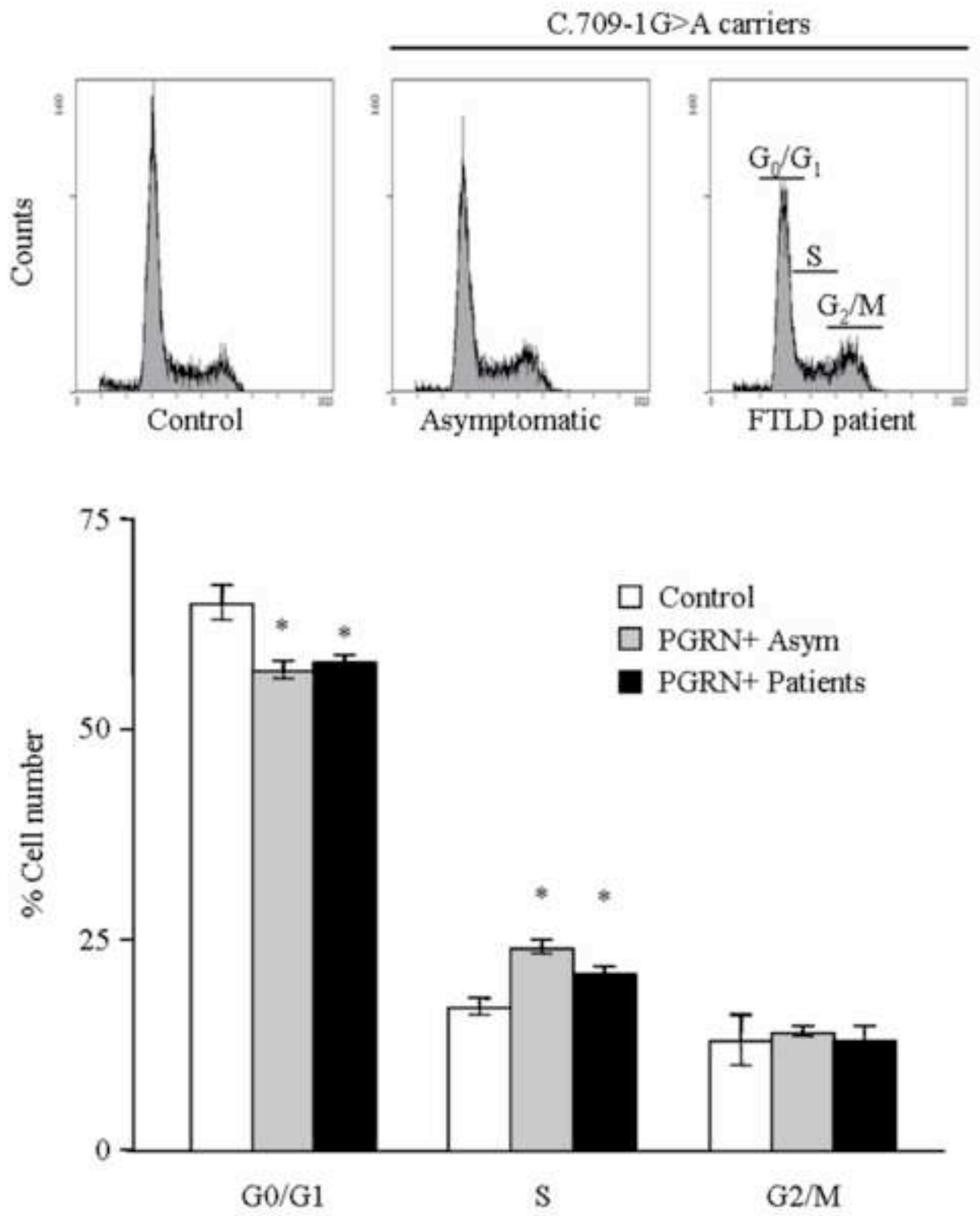

Fig. 2 


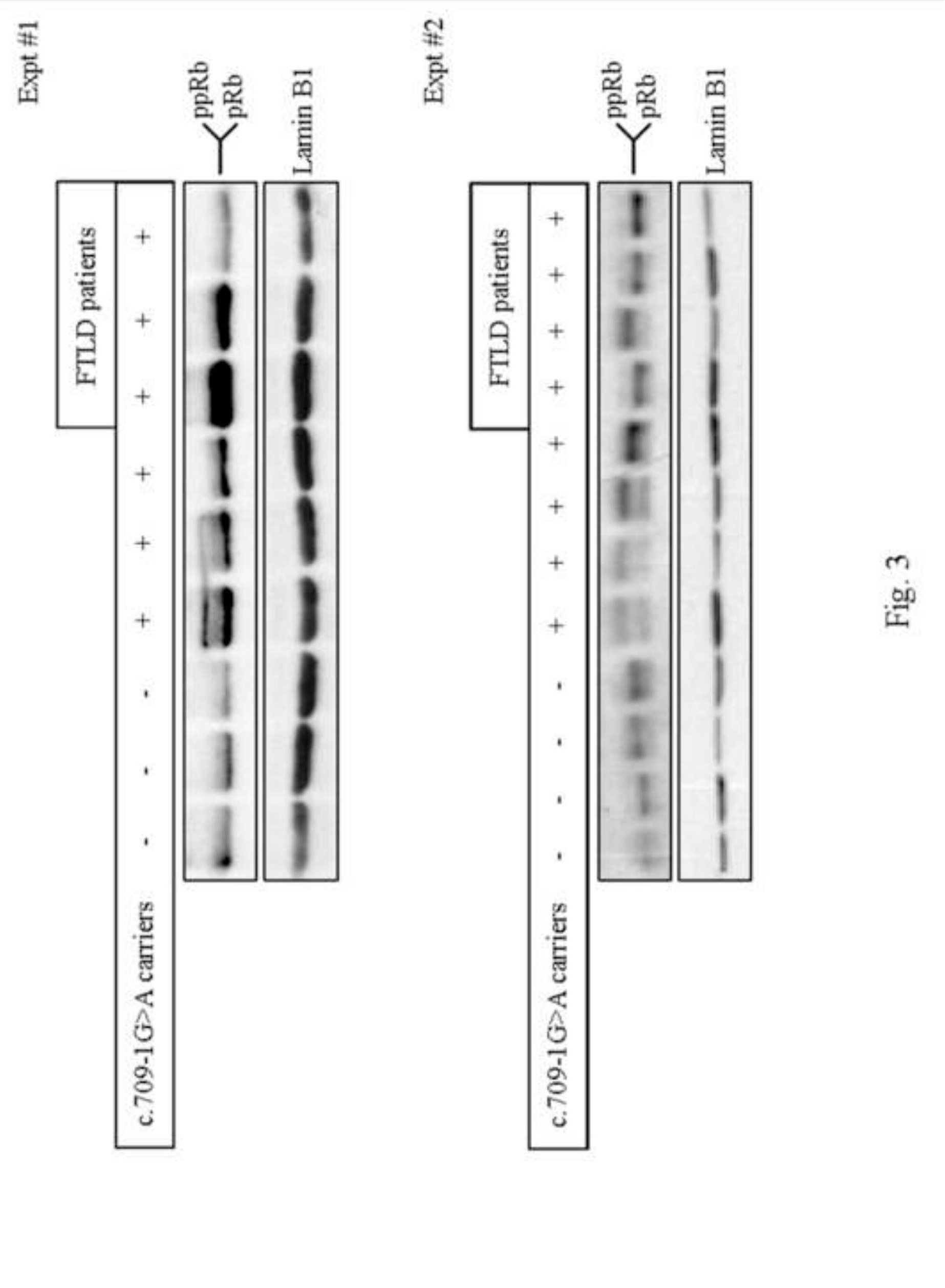


Click here to download high resolution image

Cyclin family



$\square$ Control

$\square$ PGRN+ Asym

- PGRN + Patients
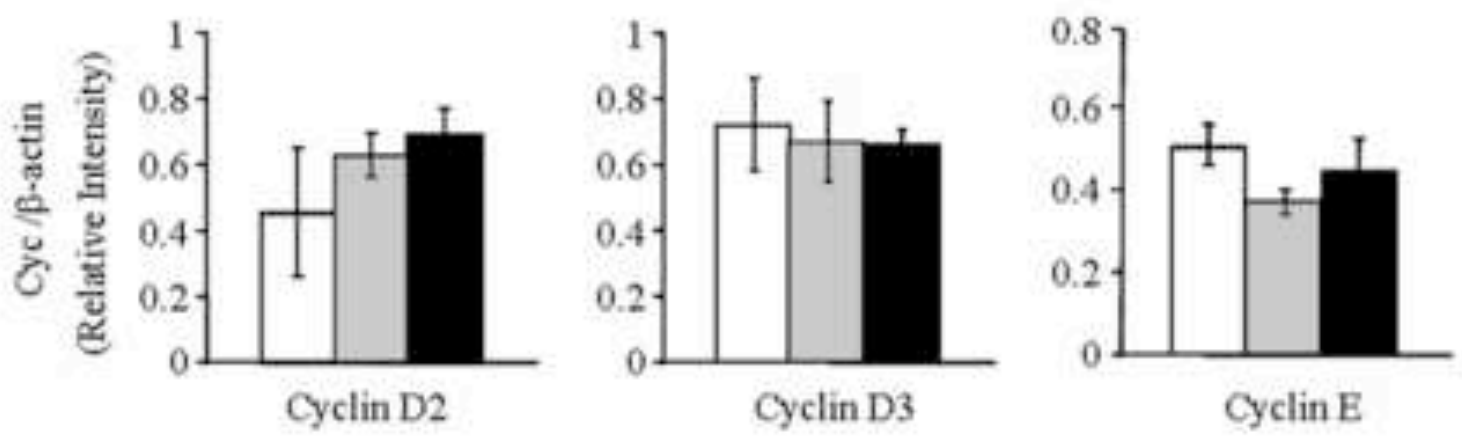

Fig. 4 
Fig. 5

Click here to download high resolution image

CDK farnily
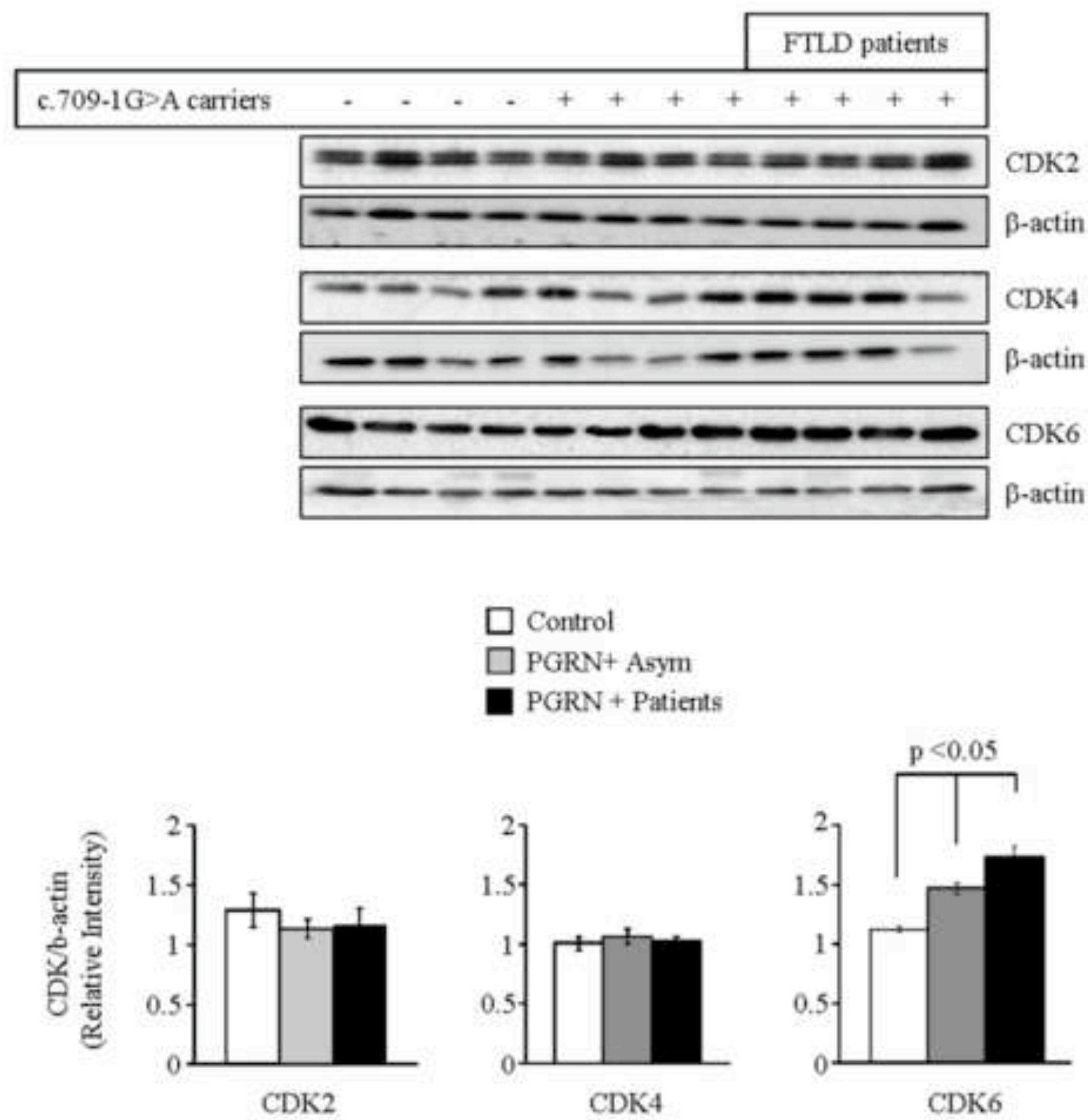

Fig. 5 
Click here to download high resolution image

CDK inhibitors

A: KIP1/CIP1

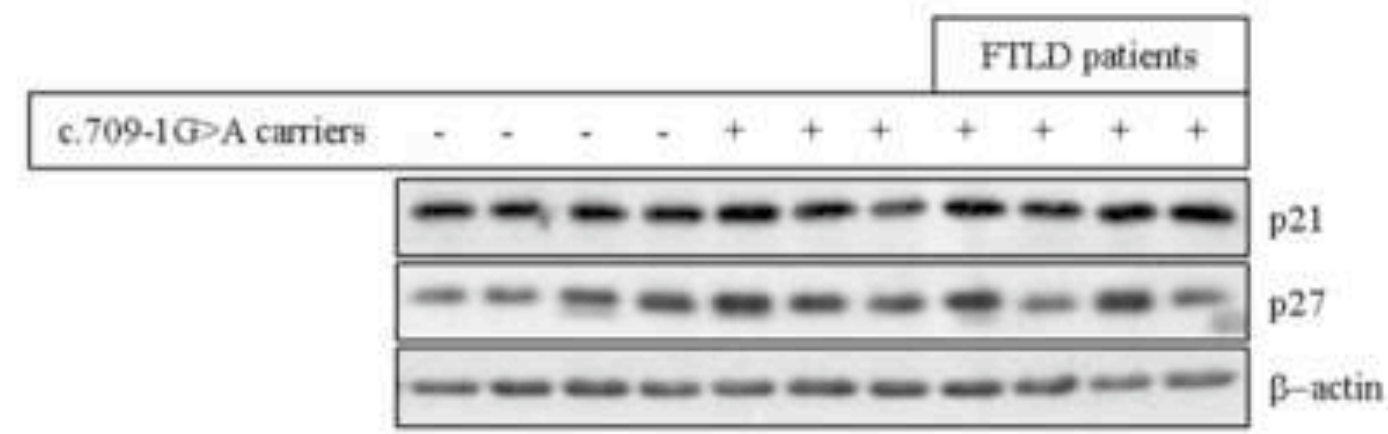

Control

PGRN + Asym

PGRN+ patients
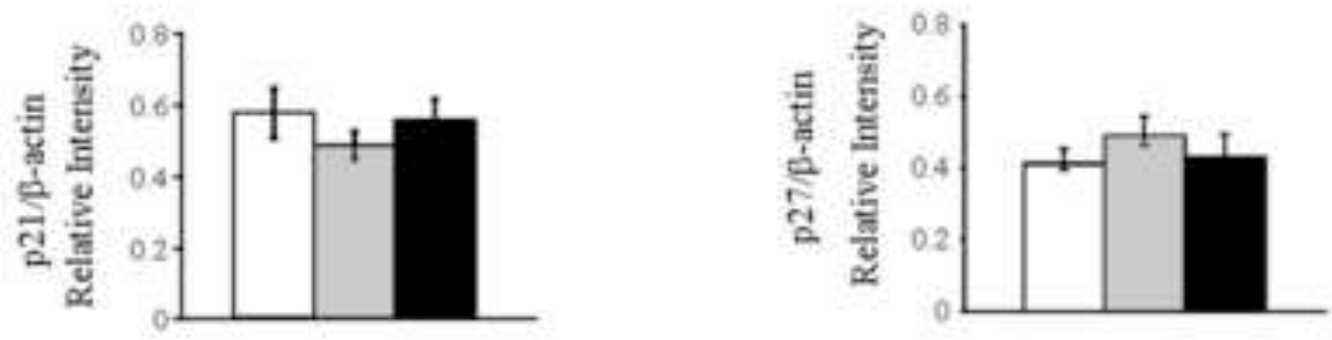

B: INK4
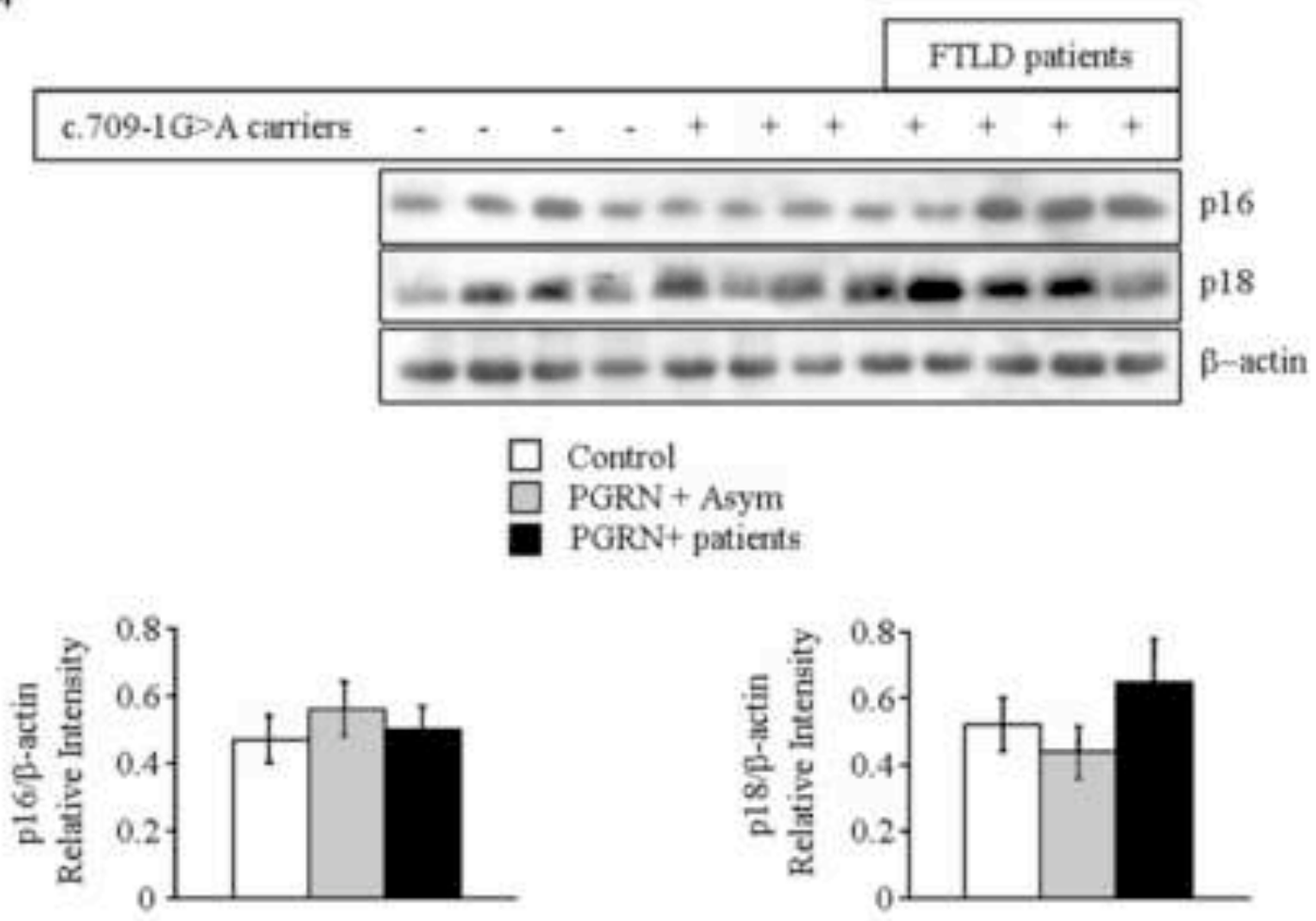

Fig. 6 
Fig.
Click here to download high resolution image

口 None

ㅁ $5 \mu \mathrm{MNaB}$

ㅁ $10 \mu \mathrm{MNaB}$

- $50 \mu \mathrm{MNaB}$

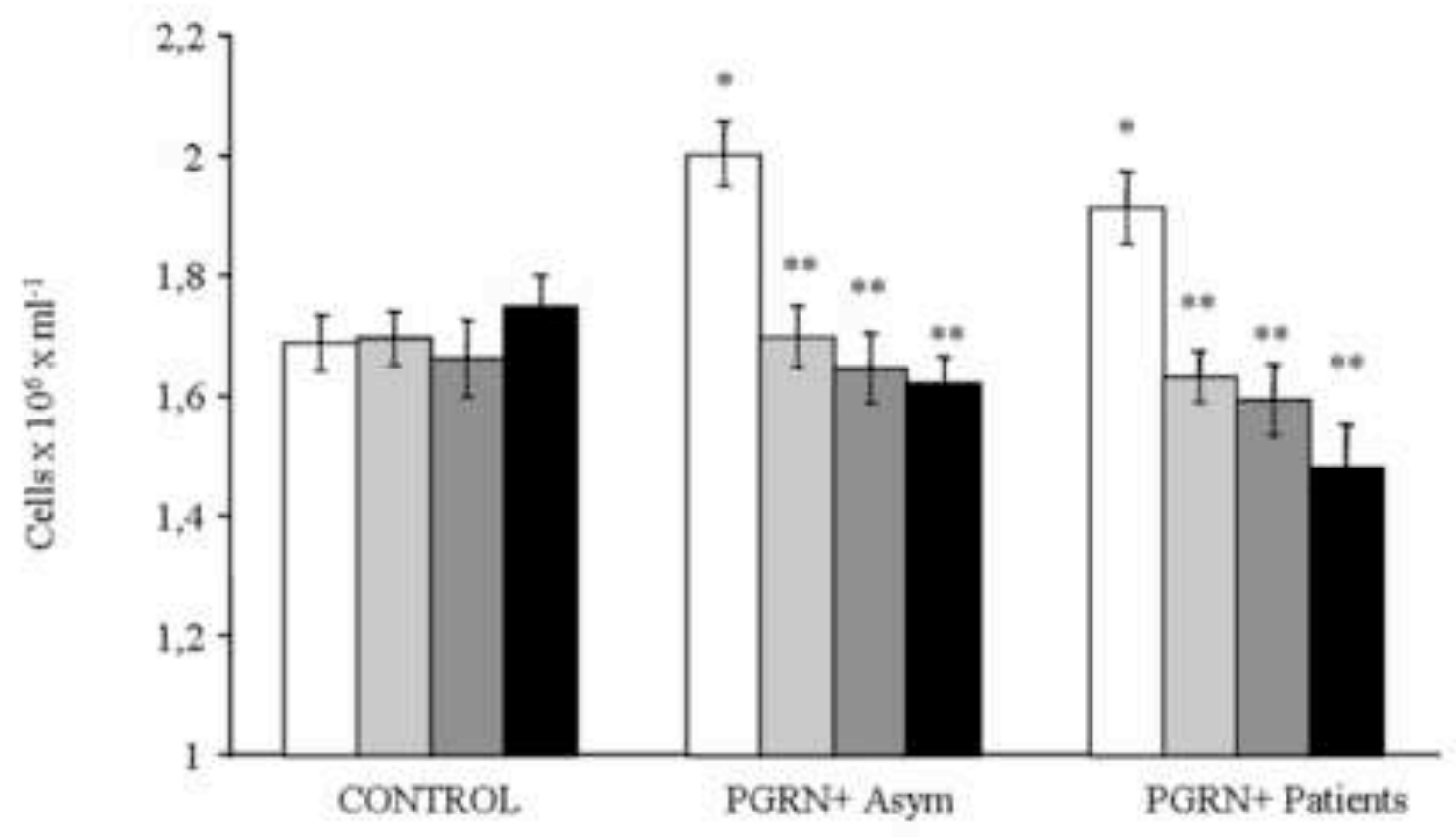

Sodium Butyrate $10 \mu \mathrm{M}:$ - + + + + +

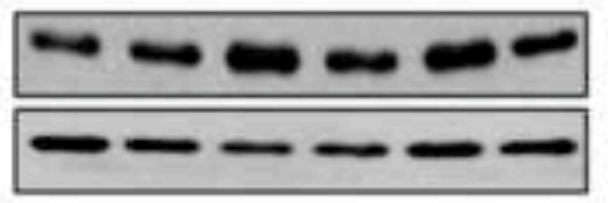

CDK6

B-actin

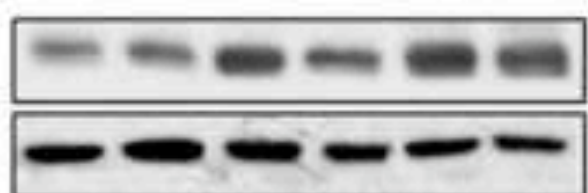

$-\mathcal{P p R B}_{\mathrm{pRb}}^{\mathrm{ppRB}}$

CONTROL

PGRN+

ASYM PATIENT

Fig. 7 
Fig.8
Click

Click here to download high resolution image

A

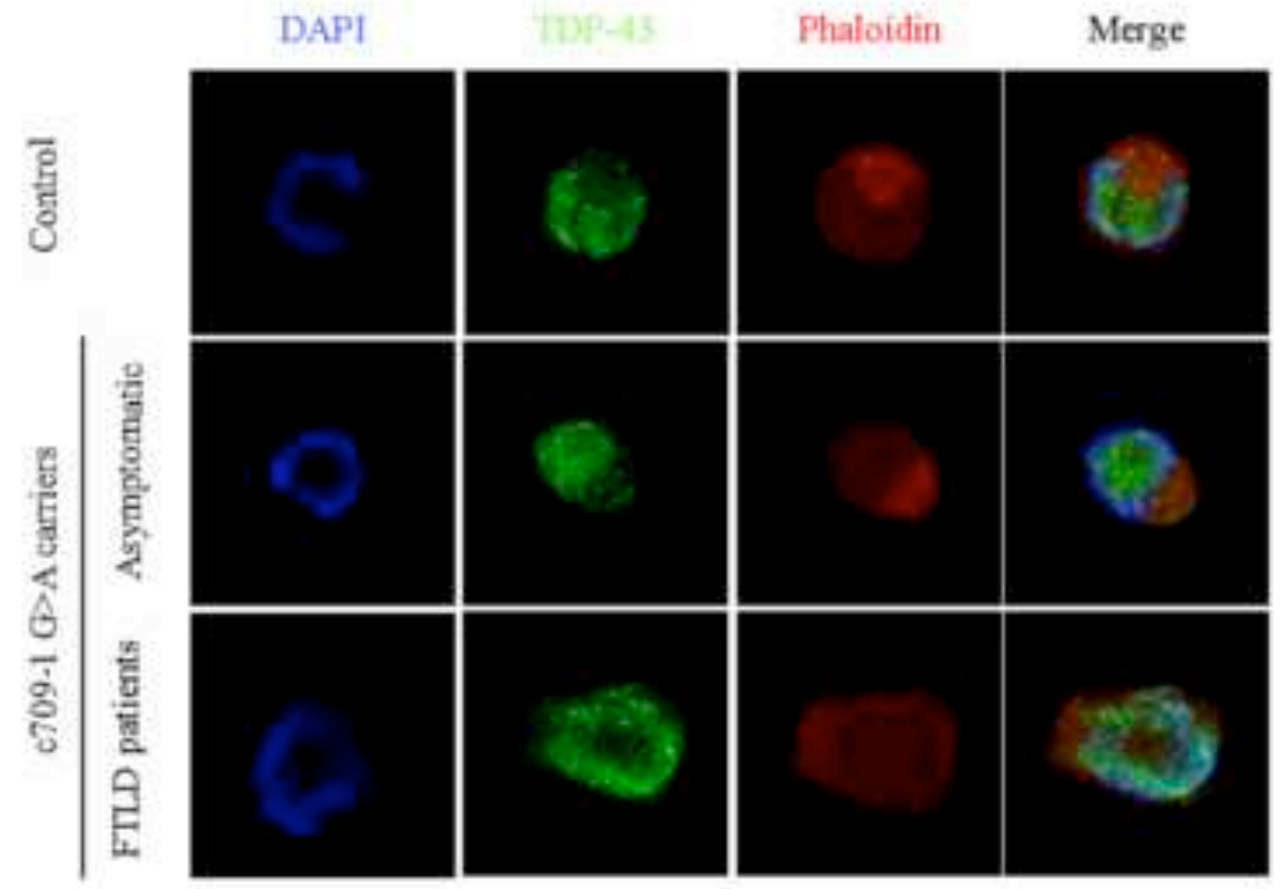

B

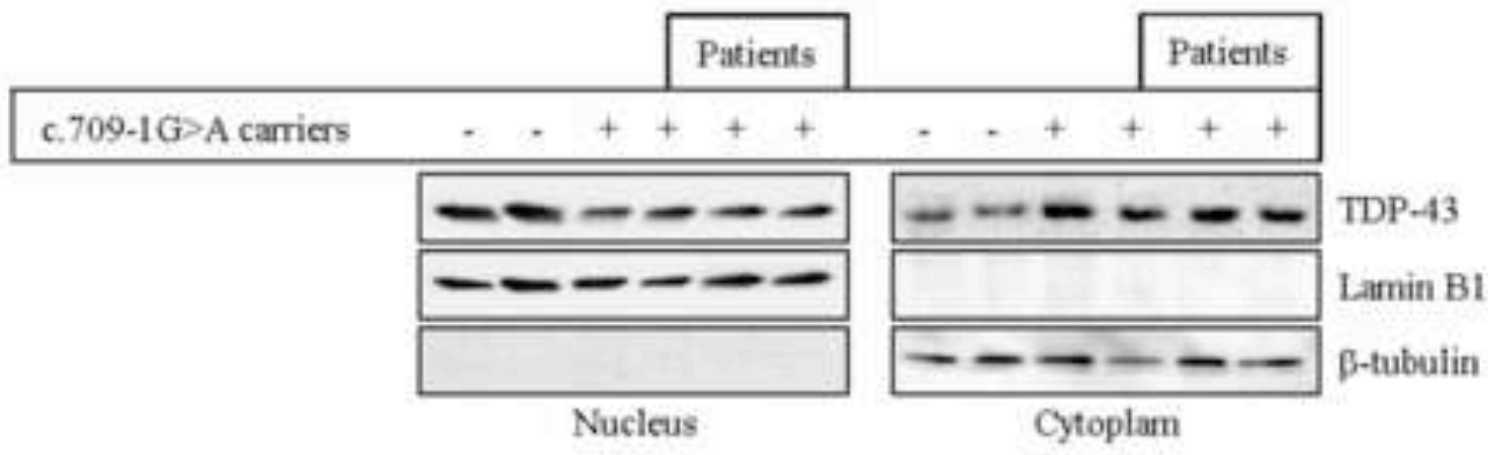
ㅁ Control
a PGRN+ Asym
- PGRN+Patients
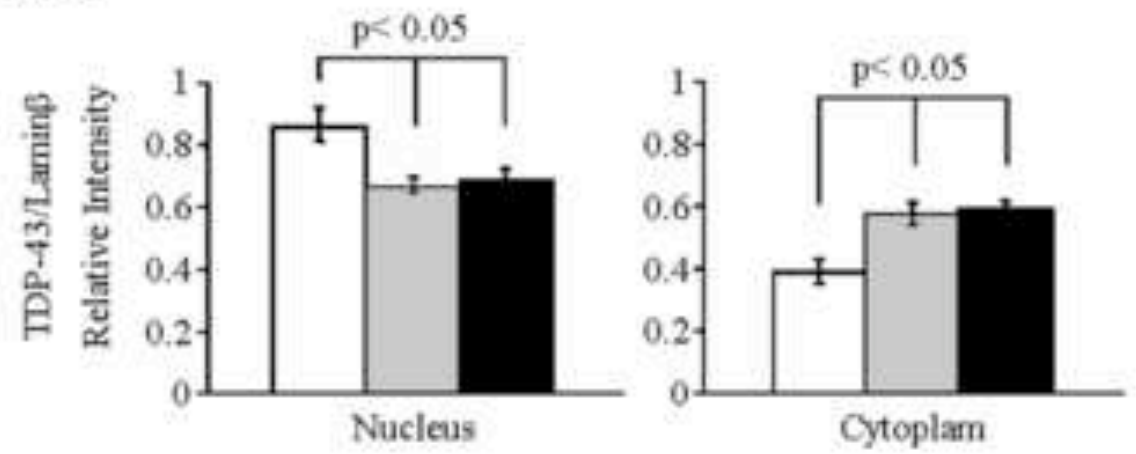

Fig. 8 